\title{
Non-surgical stem cell delivery strategies and in vivo cell tracking to injured myocardium
}

\author{
Tycho I. G. van der Spoel • Joe Chun-Tsu Lee • Krijn Vrijsen • \\ Joost P. G. Sluijter • Maarten Jan M. Cramer • Pieter A. Doevendans • \\ Eric van Belle $\cdot$ Steven A. J. Chamuleau
}

Received: 5 March 2010/Accepted: 11 June 2010/Published online: 25 June 2010

(C) The Author(s) 2010. This article is published with open access at Springerlink.com

\begin{abstract}
Heart failure is a major economic and public health problem. Despite the recent advances in drug therapy and coronary revascularization, the lost cardiomyocytes due to necrosis and apoptosis are not replaced by new myocardial tissue. Cell therapy is an interesting therapeutic option as it potentially improves contractility and restores regional ventricular function. Early clinical data demonstrated that cell transplantation, mainly delivered through nonsurgical methods, is safe and feasible. However, several important issues need to be elucidated. This includes, next to determining the best cell type, the optimal delivery strategy, the biodistribution and the survival of implanted stem cells after transplantation.
\end{abstract}

T. I. G. van der Spoel $(\bowtie) \cdot$ K. Vrijsen ·

J. P. G. Sluijter - M. J. M. Cramer - P. A. Doevendans ·

E. van Belle · S. A. J. Chamuleau

Department of Cardiology, Division Heart and Lungs,

University Medical Center Utrecht, Rm E03.511,

Heidelberglaan 100, 3584 CX Utrecht, The Netherlands

e-mail: tspoel@umcutrecht.nl

J. C.-T. Lee

Faculty of Medicine, University of Malaya,

Kuala Lumpur, Malaysia

J. P. G. Sluijter · P. A. Doevendans

Interuniversity Cardiology Institute of the Netherlands

(ICIN), Utrecht, The Netherlands
In this view, pre-clinical animal experiments are indispensable. Reporter genes, magnetic or radioactive labeling of stem cells have been developed to observe the fate and the distribution of transplanted cells using non-invasive imaging techniques. Several studies have demonstrated that these direct and nondirect labeling techniques may become an important tool in cell therapy. Integration of cell delivery and cell tracking will probably be a key for the success of cell therapy in patients. This review will provide a comprehensive overview on the various cell tracking and non-surgical cell delivery techniques, which are highly important in view of experimental and clinical studies.

Keywords Stem cells - Cell delivery · Magnetic resonance imaging $\cdot$ Nuclear imaging

\begin{tabular}{|c|c|}
\hline \multicolumn{2}{|c|}{ Abbreviations } \\
\hline BM-MNC & Bone marrow mononuclear cells \\
\hline${ }^{18} \mathrm{~F}-\mathrm{FDG}$ & ${ }^{18}$ F-Fluorodeoxyglucose \\
\hline $\operatorname{In}^{111}$ & Indium $^{111}$ \\
\hline MRI & Magnetic resonance imaging \\
\hline MSC & Mesenchymal stem cells \\
\hline MI & Myocardial infarction \\
\hline PET & Positron emission tomography \\
\hline RPG & Reporter gene \\
\hline SPECT & $\begin{array}{l}\text { Single photon emission computer } \\
\text { tomography }\end{array}$ \\
\hline SPIO & Superparamagnetic iron oxide \\
\hline${ }^{99} \mathrm{Tc}$ & ${ }^{99}$ Technetium \\
\hline
\end{tabular}




\section{Introduction}

Coronary heart disease is a major public and economic health problem leading to more than 7 million deaths world wide each year [1,2]. Optimal pharmacologic treatment and coronary reperfusion therapy have led to improved survival of patients with coronary artery disease. Clearly, current therapies can not replace dysfunctional or lossed cardiomyocytes which finally lead to heart failure. A structural solution may be provided by cell therapy which has emerged as a potential new therapeutic strategy. Cell therapy is considered in the setting of acute myocardial infarction (MI) and chronic ischemic heart failure. The ultimate goals of cell therapy are myocardial regeneration and revascularization, thereby re-establishing synchronous contractility and bioelectrical conductivity to achieve overall clinical improvement of cardiac function without severe adverse effects. Transplantation strategies include percutaneous, surgical and systemic delivery of various types of stem cells [3-7]. To monitor the efficiency of implanted stem cells, most small animal studies use post mortem histology as a gold standard [8,9]. For in vivo detection of cell retention, sophisticated imaging techniques are necessary. Additionally, non-invasive imaging is preferred to determine the effect of cell therapy on cardiac function (e.g. volume, mass and pressure). Nowadays it is possible to track and quantify transplanted stem cells by direct and non-direct labeling techniques using (1) nuclear imaging [positron emission tomography (PET) or single photon emission computer tomography (SPECT)] and (2) magnetic resonance imaging (MRI). Various clinically approved radiomarkers are suggested to be useful in cardiac cellular therapies like ${ }^{18}$ F-fluorodeoxyglucose $\left({ }^{18} \mathrm{~F}\right.$-FDG) for PET scan, indium $^{111}\left(\mathrm{In}^{111}\right)$ for SPECT and superparamagnetic iron oxide (SPIO) for MRI [10-12].

It is important to further optimize delivery strategies in view of ongoing (pre-) clinical studies for regenerative therapy. To this end, state-of-the-art cell tracking is highly necessary. This review will provide a robust update of available in vivo cell tracking strategies and non-surgical delivery techniques that will guide experimental set up of pre-clinical stem cell research.

\section{Part 1: in vivo cell tracking strategies}

In the following section the contrast agents and detectors that have been proposed for non-invasive cell tracking will be discussed. Thereafter, we will review the advantages and disadvantages of each imaging strategy and suggest future directions for research. Figure 1 and Table 1 will provide an overview of all available direct and non-direct labeling techniques.
Fig. 1 Different methods for non-invasive cell tracking. a $M R I$ magnetic resonance imaging, SPIO super paramagnetic iron oxide; b SPECT single photon emission computer tomography, indium ${ }^{111}$ $\mathrm{In}^{111}$, 99Tc 99Technetium, PET positron emission tomography, ${ }^{18}$ F FDG $18 \mathrm{~F}$ fluorodeoxyglucose; c $R P G$ reporter gene

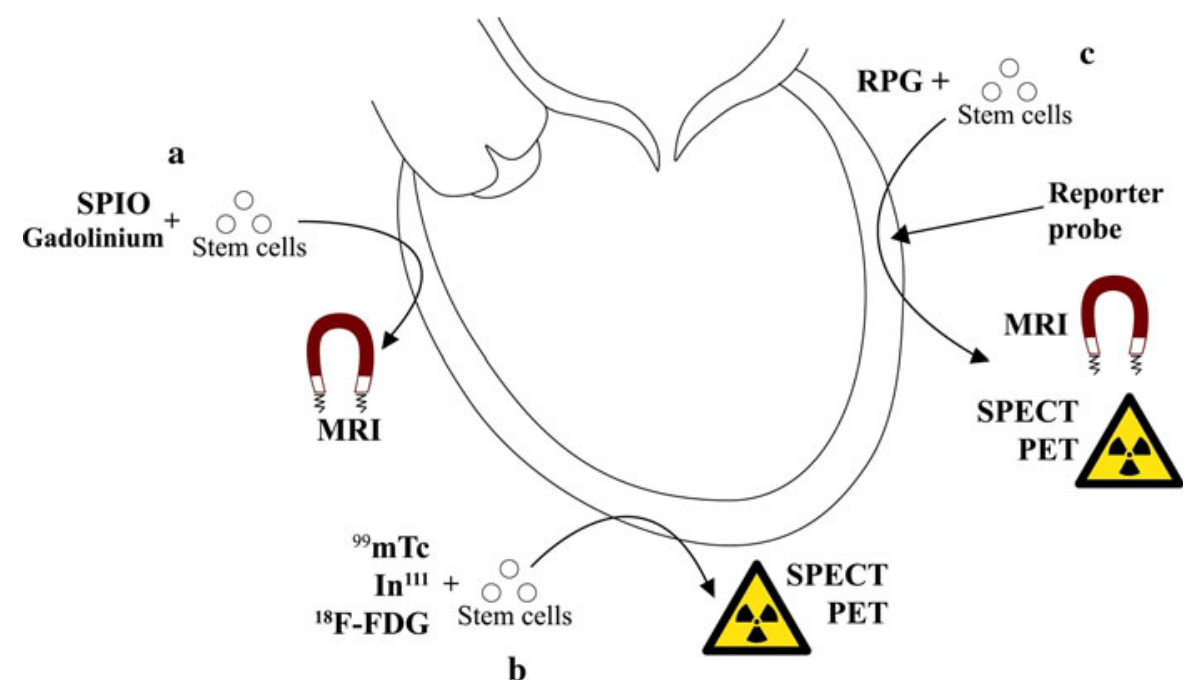


Table 1 Methods of direct and non-direct stem cell tracking

\begin{tabular}{|c|c|c|c|}
\hline Method & Label & Advantages & Disadvantages \\
\hline \multicolumn{4}{|c|}{ Direct labeling } \\
\hline MRI & Gadolinium & Simple method & $\begin{array}{l}\text { Bio-incompatible } \\
\text { Cytotoxic in unchelated form } \\
\text { Low relaxivity }\end{array}$ \\
\hline & SPIO & $\begin{array}{l}\text { Biocompatible } \\
\text { Cell friendly } \\
\text { High resolution } \\
\text { Stem cell imaging and anatomical function } \\
\text { can be assessed simultaneously }\end{array}$ & $\begin{array}{l}\text { Long incubation time for labeling } \\
\text { Dilution of the contrast } \\
\text { Signal may not reflect living cells } \\
\text { Not suitable for patients with intracardiac } \\
\text { defibrillator or pacemaker }\end{array}$ \\
\hline SPECT & $\begin{array}{l}\operatorname{In}^{111} \\
{ }^{99} \mathrm{Tc}\end{array}$ & $\begin{array}{l}\text { High sensitivity } \\
\text { Stem cell imaging and perfusion can be assessed } \\
\text { simultaneously }\end{array}$ & $\begin{array}{l}\text { Radiation exposure to patients and neighbouring } \\
\text { cells } \\
\text { Low cellular retention } \\
\text { Possible effect of radioactivity on transplanted cells } \\
\text { Signal may not reflect living cells } \\
\text { Signal loss due to radioactive decay }\end{array}$ \\
\hline PET & ${ }^{18} \mathrm{~F}-\mathrm{FDG}$ & $\begin{array}{l}\text { High spatial resolution } \\
\text { No cytotoxicity } \\
\text { Stem cell imaging and myocardial vitality } \\
\text { can be assessed simultaneously }\end{array}$ & $\begin{array}{l}\text { Radiation exposure to patients } \\
\text { Signal may not reflect living cells } \\
\text { Signal loss due to radioactive decay }\end{array}$ \\
\hline \multicolumn{4}{|c|}{ Non-direct labeling } \\
\hline RPG & $\begin{array}{l}\text { Reporter genes/ } \\
\text { probes }\end{array}$ & $\begin{array}{l}\text { Detection of viable cells } \\
\text { Observation of cell differentiation }\end{array}$ & $\begin{array}{l}\text { Cellular dysfunction or death } \\
\text { Immunogenicity of gene products } \\
\text { Potential risk of uncontrolled growth } \\
\text { and malignancy } \\
\text { Costs } \\
\text { Not used in patient studies }\end{array}$ \\
\hline
\end{tabular}

MRI magnetic resonance imaging, SPIO super paramagnetic iron oxide, SPECT single photon emission computer tomography, $I^{111}$ indium ${ }^{111},{ }^{99} T c{ }^{99}$ technetium, $P E T$ positron emission tomography, ${ }^{18} F-F D G{ }^{18}$ F-fluorodeoxyglucose, $R P G$ reporter gene

MRI

For MRI, Gadolinium- and iron-based contrast agents can be used for direct labeling of stem cells. Gadolinium is bio-incompatible, cytotoxic in unchelated form and has a low relaxivity; therefore it is an unattractive agent for stem cell imaging. However, novel Gadolinium-based particles are being investigated for this purpose, albeit not yet in the heart [13].

In 1996, SPIO's (30-200 nm) were approved as iron-based contrast agents for clinical use by the US Food and Drug Administration (Feridex, Guerbet, France). SPIO's are composed of an iron oxide core that is coated with a polymer shell to prevent aggregation. The polymer may contain dextran, polyethylene glycol or starch. The iron is biocompatible and can be recycled by cells using regular biochemical pathways. Labeling of targeted cells is accomplished by endocytosis. In addition, efficiency can be improved by using peptides/antibodies [14], magnetodendrimers [15] or transfection agents [16]. Labeled cells appeared to be hypo intense in $\mathrm{T} 2{ }^{*}$ - and $\mathrm{T} 2$-weighted images.

Numerous studies have shown that mesenchymal stem cells (MSC) can be labeled without affecting in vitro cell viability, proliferation and differentiation into adipogenic and osteogenic lineages by iron contrast agents [10, 16, 17]. Recently, pre-clinical studies were able to detect a minimum of about $10^{5} \mathrm{pig}$ MSC using different sized iron particles with a conventional cardiac MRI [10, 12]. Figure 2 shows an example of cell tracking by cardiac MRI using SPIO labeled MSC from our own laboratory. Detection of 


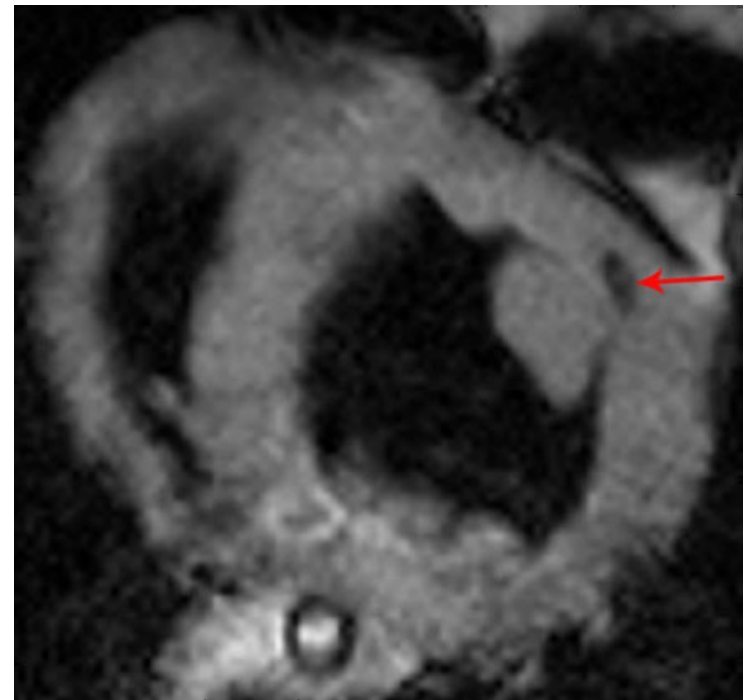

Fig. 2 T2* image of SPIO labeled MSC (arrow) after transepicardial injection in healthy myocardium

stem cells mainly depends on (1) magnetic field strength, (2) number of cells injected, (3) labeling efficiency and (4) cell size.

A practical drawback of iron-based contrast agents is that labeling is not permanent and self-replicable. Dilution of the contrast due to cellular fragmentation, fusion, division and migration also limits the use for follow-up after cell delivery. Also, variation in labeling efficiency among different cell types is present. For instance, SPIO-registered MR signals are still detectable in embryonic stem cells [18] 5 weeks after transplantation and 4-16 weeks for skeletal myoblasts [19] and MSC in murine models [20], respectively. Very little is known about the long-term survival after cell delivery in both pre-clinical models and humans. Furthermore, iron particles may still remain in situ and can be taken up by phagocytotic cells (e.g. cardiac macrophages) after cellular death [21]. Thus, MRI signal is still present leading to overestimation of the outcome of cellular survival ('false positive' results). Another potential drawback is negative image contrast artifacts due to air or hemorrhage after cell injection. Finally, patients with an intracardiac defibrillator or pacemaker are no candidates for MRI.

Magnetic resonance imaging has become an appropriate imaging modality for stem cell tracking and therapeutic efficacy, without ionic radiation, high spatial resolution and detailed anatomical function.
Nevertheless, at present this method is only useful for establishing initial retention of cells as it provides little evidence for long-term viability or functionality of transplanted cells. None of the MRI contrast agents have been used in the clinical field to monitor cellular survival. More information about long-term cell tracking and effects on cell behavior (e.g. differentiation and proliferation) in large animal studies is mandatory before applying this technique to clinical stem cell trials.

\section{SPECT}

Several radioisotopes are available for stem cell tracking in the heart, Technetium $\left({ }^{99} \mathrm{Tc}\right)\left(\mathrm{T}^{1 / 2} 6 \mathrm{~h}\right)$ and $\operatorname{In}^{111}\left(\mathrm{~T}^{1} / 2\right.$ 2.6 days). Labeling is based on established clinical protocols for white blood cells and performed by chelating agents that carry the radionuclides into the cell. Radioactivity is measured by a Gamma camera composing a 3D image.

In vitro studies have shown that cell integrity of both human and canine MSC, and endothelial progenitor cells (EPC) were unaffected after $\mathrm{In}^{111}$ labeling with 0,14-30 Becquerel per cell [22-24]. However, radiation induced cell damage was found after labeling hematopoietic progenitor cells (HPC) with $\operatorname{In}^{111}[25,26]$. In addition, low cellular retention after labeling was observed in all cell types [26-28]. Penicka et al. [29] observed high retention of ${ }^{99} \mathrm{Tc}$ inside bone marrow mononuclear cells (BM-MNC) and no altered proliferation pattern after labeling. Cell viability of MSC was also not influenced by ${ }^{99} \mathrm{Tc}$ [30]. The effect on cell differentiation was not determined in these studies. The use of SPECT is accompanied by a low detection threshold of about $10^{4}$ cells [24] and therefore it is an attractive tool to determine in vivo biodistribution.

Both isotopes have been studied in various large animal models to determine cellular homing after surgical, intramyocardial (IM) and intravenous (IV) delivery [12, 27, 31, 32]. It was shown that a low number of cells accumulate in the heart after injection. However, when injecting cells into healthy myocardium $1 / 3$ of the total radioactivity was still located in the heart [33]. Figure 3 shows a typical example of cellular retention of radioactive labeled stem cells after surgical injection in one of our experiments. Zhou et al. [34] showed that it is possible to simultaneously assess stem cell imaging 


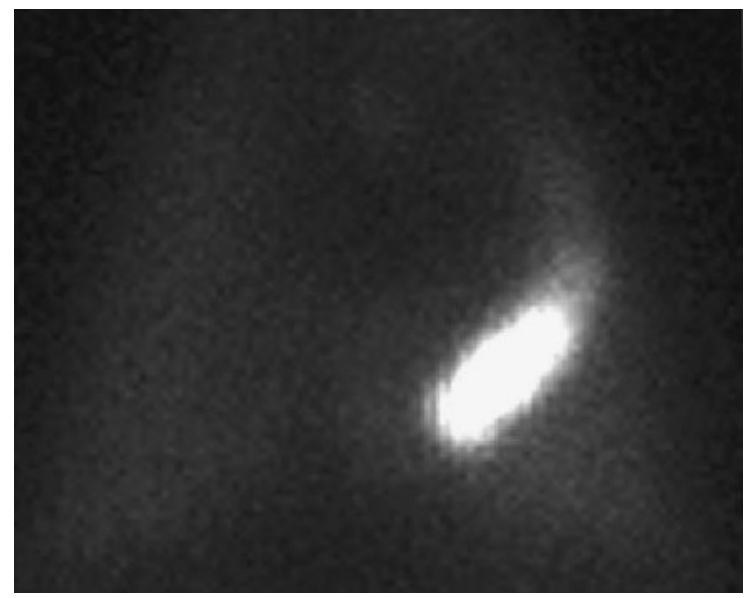

Fig. 3 SPECT image of indium ${ }^{111}$ labeled MSC in the heart after surgical injection in the left ventricle wall in a healthy porcine model

and perfusion in a rat model using dual isotope SPECT by combining both $\operatorname{In}^{111}$ (for cell imaging) and ${ }^{99} \mathrm{Tc}$ (for perfusion study). This interesting finding should be confirmed in a pre-clinical model.

In humans, SPECT was employed to study the kinetics of ${ }^{99} \mathrm{Tc}$ or $\mathrm{In}^{111}$ labeled progenitor cells after intracoronary (IC) delivery in a small number of patients with ischemic heart disease. In general, low retention rates of progenitor cells $(<10 \%)$ to the infarcted myocardium were found $1-2 \mathrm{~h}$ after injection [29, 35, 36]. Signal loss due to reduction in activity also limits the use of radioisotopes for longterm follow-up.

Single photon emission computer tomography is an attractive approach to determine delivery efficiency. In Table 3, all studies on cell delivery efficiency are summarized per strategy. Animal studies have shown that SPECT imaging is a promising tool to visualize in vivo migration patterns and to assess functional effects of transplanted stem cells. However, the negative effect of radioisotopes on cell behavior (e.g. radiation induced cell damage, possible reduced differentiation rates) can not be neglected in view of clinical use.

\section{PET}

Positron emission tomography is a well known method to determine myocardial viability and perfusion by injecting ${ }^{18}$ F-FDG. It is possible to label stem cells with ${ }^{18} \mathrm{~F}-\mathrm{FDG}$ to monitor homing and biodistribution (see Table 3). No cytotoxicity, or impaired stem cell differentiation were documented after ${ }^{18} \mathrm{~F}$-FDG labeling. This could be due to the radioactive properties of ${ }^{18} \mathrm{~F}$-FDG, that emits a long range beta particle and thereby prevents radiation injury inside the cell. Although PET imaging offers high spatial resolution, the short half lifetime remains an obstacle for long-term cell tracking.

In a porcine MI model, dynamic cell tracking of percutaneous implemented ${ }^{18} \mathrm{~F}$-FDG labeled circulating progenitors cells was demonstrated: only $8-18 \%$ of myocardial activity was retained $1 \mathrm{~h}$ after IC delivery [37]. Similar results were obtained when autologous BM-MNC's were infused to the heart [38]. In addition, ${ }^{18}$ F-FDG was used to label and determine myocardial homing and biodistribution of BM-MNC after IC and IV delivery in post-acute MI patients. Low amount of BM-MNC activity was detected in the infarcted myocardium after injection (less than 3\%) [11]. Both studies demonstrate the importance of metabolic myocardial imaging to determine cellular survival and a potential effect on scar tissue. However, larger (pre) clinical randomized studies on this topic are required to establish early and late biodistribution after cell delivery. Furthermore, a metabolic isotope with a longer half lifetime is necessary for chronic cell tracking.

\section{Reporter genes}

To solve limitations in traditional cardiovascular imaging (i.e. false positive findings after cell death and cell toxicity), reporter genes (RPG) may be an attractive alternative. In short, a genetically engineered gene (the RPG) is incorporated into the genome of a cell prior to transplantation. The gene product should only be expressed by engrafted and still viable cells. Next, cells can be visualized after IV injection of an imaging tracer that targets the gene product. By its presence, the survival of the graft is certain because expression of the RPG and activity of the gene product depends on the viability of transplanted cells. Enzyme, transport and receptor based gene products are available for molecular imaging.

This strategy is particular well suited to overcome dilution effects which ensure long-term serial imaging of living transplanted stem cells. Also, repetitive imaging is possible and does not depend on decay of the radioisotope. Potential disadvantages 
include (1) costs, (2) cellular dysfunction or death, (3) immunogenicity of gene products, (4) potential risk of uncontrolled growth and malignancy; these aspects preclude clinical application in patients at this time. Several RPG's (transferrin receptor (TR), herpes simplex virus type 1 thymidine kinase (HSV1) and human sodium/iodide symporter) have been developed for non-invasive imaging in living animals [39-41]. The transferrin receptor has been proposed as a RPG for MRI [42]. High expression of TR on the cell membrane leads to increased iron uptake that is detectable by MRI and does not depend on intracellular iron concentration. Moreover, detection may be improved by covalent binding with iron nanoparticles [42]. However, accumulation of iron may lead to high levels of intracellular iron and diminished cellular function. Furthermore, not much is known about efficacy and safety of TR in large animal models and humans.

Herpes simplex virus type 1 thymidine kinase is being used for nuclear imaging [40]. Radioisotopes analogous to thymidine and guanosine are used as tracers. After metabolizing, the substrate is trapped intracellularly. Free radioactivity is detectable by PET or SPECT. In 2003, feasibility was tested to monitor survival of cardiomyoblasts after IM delivery using HSV1 thymidine kinase RPG. It was shown that optical imaging was more sensitive for detecting cardiomyoblasts $\left(5 \times 10^{5}\right)$ than PET $\left(3 \times 10^{6}\right)$ [40, 43]. Furthermore, HSV1 thymidine kinase can be transduced in human MSC and visualized in a clinical relevant swine model with healthy myocardium [44]. In 2008, Gyöngyösi et al. [45] demonstrated the feasibility of PET and optical imaging of the stable expressed of the trifusion gene protein (luciferase) for in vivo non-invasive tracking of IM injected MSC in a relevant animal model with survival up to 10 days after injection. Data on HSV1 thymidine kinase and long-term follow-up are currently not available.

Human sodium/iodide symporter controls the membrane conductance of sodium and iodine. It is mainly expressed in the thyroid gland, and it is absent in cardiac cells [46]. Therefore, isotopes for both PET and gamma camera can be used to image cells that express this gene. More detailed information about the effect of sodium influx on cardiomyocytes is required before entering the clinical field.
So far, the available data is limited to reveal the role of RPG in cellular tracking. Up till now, just one study attempted to initiate RPG imaging in an ischemic large animal model. Before human administration, a safe and stable RPG with no effect on cell behavior has to be developed. In parallel, optimal detection signal and more efficient delivery routes have to be established. Nevertheless, in our view RPG is a promising concept for reliable cell tracking with respect to pre-clinical studies that address optimal cell delivery strategies and chronic longterm follow-up.

\section{Comparison of imaging techniques}

At present, various direct and non-direct labeling strategies have been investigated for in vivo cell tracking. No technique has emerged as the most optimal tracking method. Fate and biodistribution after IV delivery by colabeling allogenic MSC with $\mathrm{In}^{111}$ and SPIO was observed. Migration of low amount of cells to the heart could be detected by SPECT, but not by MRI [12]. A combined approach using SPECT and cardiac MRI was used to determine function and precise visualization of $\mathrm{In}^{111}$ labeled stem cells in an ischemic rat model [47]. Simultaneous detection of stem cells and imaging of both perfusion deficit and myocardial function of the ischemic area was done by signal coregistration. Bioluminescence firefly luciferase RPG was more accurate compared to SPIO for long-term cell survival using optical and magnetic imaging [48].

In patients, imaging is mainly performed to determine the effect of cell therapy on myocardial function and perfusion. To the best of our knowledge, no direct clinical comparison between imaging techniques has been performed to observe homing and distribution of transplanted human stem cells.

In summary, nuclear imaging is more sensitive than MRI for short-term cell tracking. For high spatial resolution and evaluation of cardiac function MRI is more appropriate. In case of long-term follow-up, iron particles and RPG can play an important role. In our view, a multimodality approach using both magnetic and nuclear radioagents in combination with RPG would provide a solution to current limitations in cell tracking in the near future. 


\section{Part 2: non-surgical methods of cell delivery}

The main objective of various cell delivery methods is to inject sufficient number of cells into the myocardium and to keep maximum retention of cells within the area of interest. A summary of the different cell delivery routes in clinical and pre-clinical setting will be provided (Fig. 4; Table 2) and also directions for future research are discussed.

\section{Intracoronary delivery}

During routine cardiac catheterization, IC delivery is performed through the central lumen of an over-wire balloon catheter that is advanced into the coronary artery of interest. By using transient balloon inflations, the duration of cell delivery is maximized,

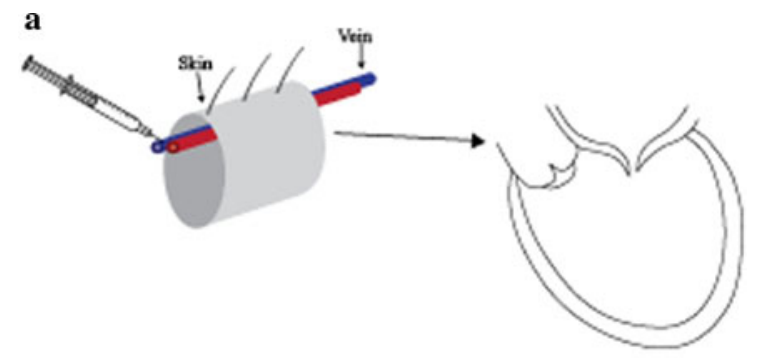

b
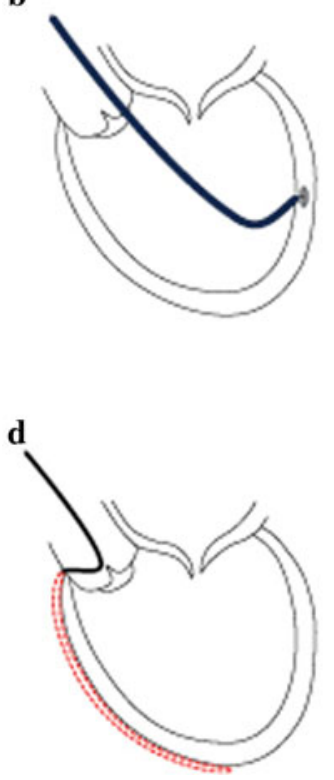

c

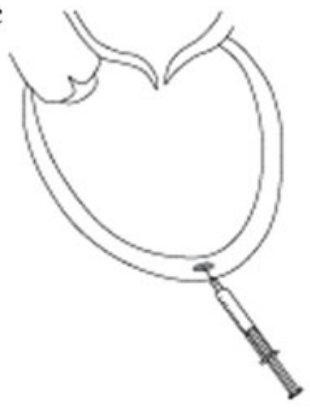

e

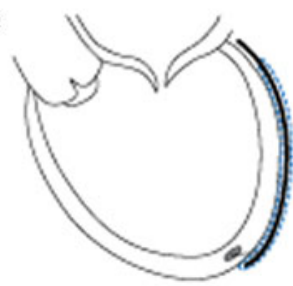

Fig. 4 Schematic overview of the different delivery techniques to the injured myocardium. a Intravenous infusion b Trans-endocardial delivery c Surgical delivery d Intracoronary infusion e Retrograde coronary transvenous injection

leading to migration of the delivered cells to the infarct related area. A major advantage of IC delivery is direct infusion into the target area using infarct related or a contralateral artery.

Based on animal and patient studies Strauer et al. looked for a non-surgical method for autologous cell therapy [7, 49]. In 2002, IC infusion of autologous BM-MNC appeared to be promising method for cell delivery in ten patients with acute MI [50]. Since then, a number of clinical trials have been conducted [51-60]. These studies showed that IC infusion was a safe delivery strategy and associated with a modest increase in myocardial function in patients with ischemic heart disease. Nevertheless, 5-year followup data of cell therapy demonstrated no significant improvement in left ventricle ejection fraction (EF) compared to placebo [61, 62]. In 31 clinical studies performed sofar, 22 used IC infusion as delivery strategy in approximately 1,200 patients, despite unresolved issues regarding this transplantation technique [63].

Important drawbacks of IC delivery are known, including the impossibility to access to the area of interest in patients with chronic occlusion. Other potential disadvantages of IC delivery of cells include intimal dissection [64, 65], embolization of these cells from the site of injection to the microvasculature in the heart leading to micro infarctions [66] or abdominal region [6] and in-stent restenosis due to transient balloon inflation [67]. Finally, imprecise localization and systemic delivery to non-cardiac tissues are limitations of IC therapy [68]. This can be explained by inadequate cellular migration into the myocardium during the first transit of coronary reperfusion causing a considerable loss of cells to the systemic circulation. A large portion of these cells are found in non-cardiac tissues, like lungs and liver $[68,69]$. It has been shown that approximately $2 \%$ of the infused non-enriched BM-MNC home to the target area of cardiac injury in humans [11]. However, a higher retention (14-39\%) in the infarcted myocardium was observed when using enriched BMMNC [11]. This effect may be caused by differences in injected cell numbers. Notably, most clinical trials used non-enriched BM-MNC.

Many cell types have been used to treat MI using IC delivery in the (semi) acute setting. Although initial results were positive, low delivery efficiency remains an obstacle for clinical application. 
Table 2 Advantages and disadvantages of stem cell delivery methods

\begin{tabular}{|c|c|c|}
\hline Method & Advantages & Disadvantages \\
\hline Intracoronary delivery & $\begin{array}{l}\text { Direct infusion infarct related or contralateral } \\
\text { coronary artery } \\
\text { Well known technique by cardiologists }\end{array}$ & $\begin{array}{l}\text { In-stent restenosis } \\
\text { No access to occluded coronary artery } \\
\text { Embolisation of microvessels, leading to } \\
\text { (micro) infarction } \\
\text { Intima dissection } \\
\text { Vascular access complications } \\
\text { Systemic delivery to non-cardiac tissues }\end{array}$ \\
\hline $\begin{array}{l}\text { Catheterized peripheral } \\
\text { vein delivery }\end{array}$ & $\begin{array}{l}\text { Non-invasive and easy method } \\
\text { Allows intermittent cell infusion }\end{array}$ & $\begin{array}{l}\text { Microembolism } \\
\text { Low cellular migration and differentiation } \\
\text { Low delivery efficiency }\end{array}$ \\
\hline Trans-endocardial injection & $\begin{array}{l}\text { Cell delivery in occluded areas } \\
\text { Implementation of high cell concentration in } \\
\text { the ischemic region } \\
\text { Assess non-viable myocardium before } \\
\text { transplantation }\end{array}$ & $\begin{array}{l}\text { Requires training; lengthen time of procedure } \\
\text { Expensive method } \\
\text { Risk of myocardial perforation } \\
\text { Arrhythmias } \\
\text { Vascular access complications }\end{array}$ \\
\hline $\begin{array}{l}\text { Retrograde coronary transvenous } \\
\text { injection }\end{array}$ & $\begin{array}{l}\text { Low costs } \\
\text { May enter thinned myocardium due its } \\
\text { co-axial injection technique }\end{array}$ & $\begin{array}{l}\text { May cause irreversible damage to venous wall } \\
\text { Perforation of the vein } \\
\text { Only access to the anterior wall along the vein } \\
\text { Technical difficult procedure } \\
\text { Vascular access complications }\end{array}$ \\
\hline
\end{tabular}

In general, this technique can not be used in chronic ischemic heart failure patients with occluded arteries. In addition, most studies related to IC infusion are small and lack of long-term follow-up data. In the future, research should focus on larger, blinded, randomized trials in MI patients with long-term follow-up to investigate the immediate and sustained effect of IC delivery.

\section{Catheterized peripheral vein delivery}

Cell delivery can be achieved by direct IV infusion of cells into a catheterized peripheral vein. Although it is an easy and safe method for cell delivery [3, 4], non-cardiac uptake of stem cells after systemic delivery remains a major obstacle for clinical application [27, 69, 70]. Moreover, several studies have shown that no $(0 \%$ of injected) cells retained in the heart (see Table 3). Additionally, the occurrence of microembolism in non-cardiac organs due to cellular entrapment of cell types with large diameter (e.g. skeletal myoblasts or MSC) is an important drawback.

In our view, this technique is currently obsolete for clinical cardiac stem cell therapy. In case of future specific cardiac targeting of stem cells for optimal homing and engraftment, this technique can possibly re-enter the research arena.

\section{Intramyocardial delivery}

Nowadays, percutaneous injection of cells for cardiac repair directly into the injured myocardium is possible. Two delivery techniques are available for percutaneous IM injections: trans-endocardial injection (TE) and retrograde coronary transvenous (RCV) injection.

Trans-endocardial injection

Five different IM injection catheters are available for clinical use: Steerjet (MicroHeart) [71], Stiletto 


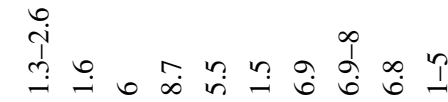

$0000 \%$

तै

$+\stackrel{n}{n} m$

$\Xi$

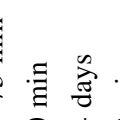

春慁

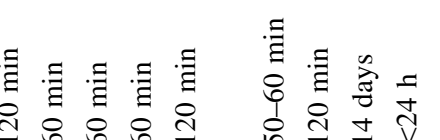

$\therefore 8788788.7$

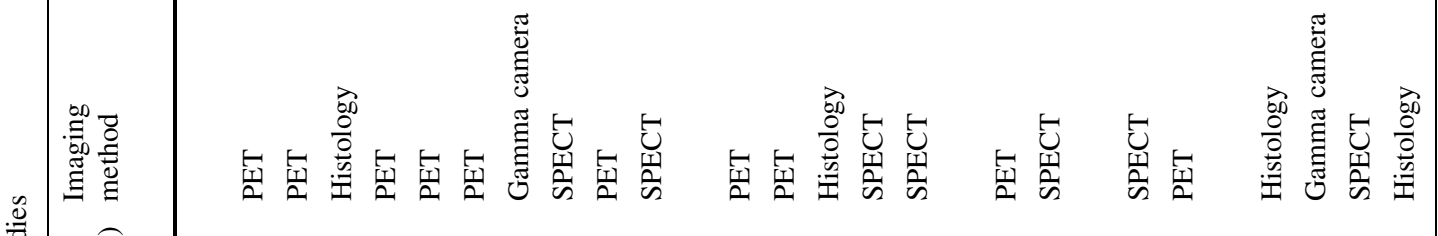

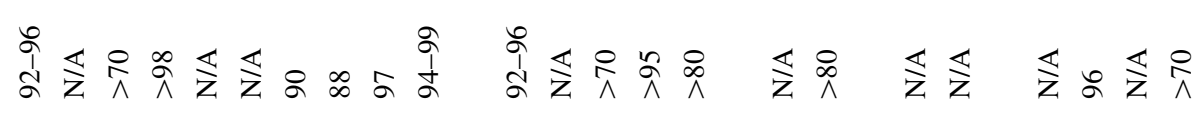

ウิ๖

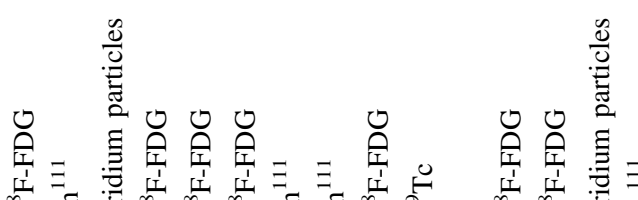

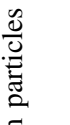

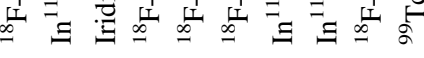

$\sum_{i}^{U} \sum_{i}^{U}$

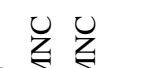

$\sum_{i}^{U}$

证

寻寻

寻寻寻突

|숭

E. 言 恶

章芒

$\Xi \succeq$

इ

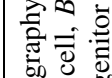

要

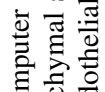

ปิ

.

छี

绕产

ํ.

क 뭉

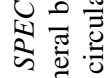

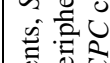

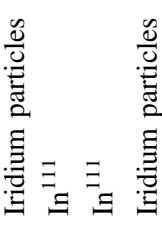

氙语

के ई

焉客

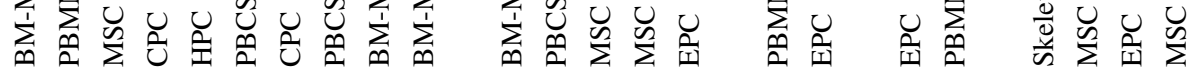

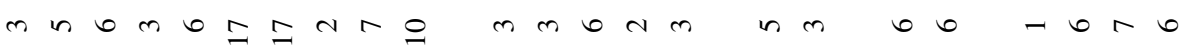

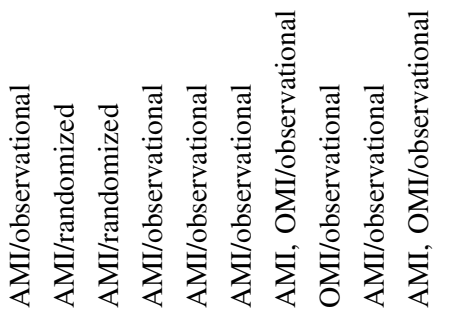

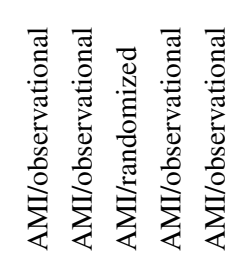

$\frac{0}{\frac{0}{0}}$

它

西

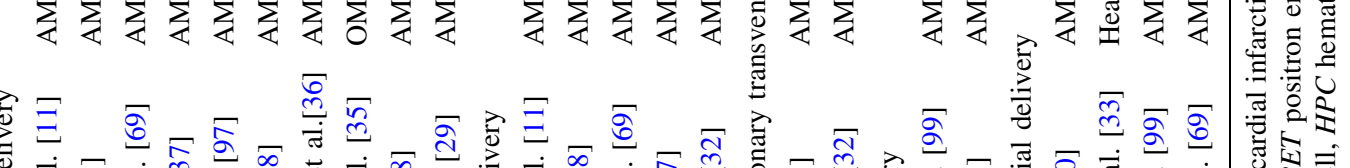

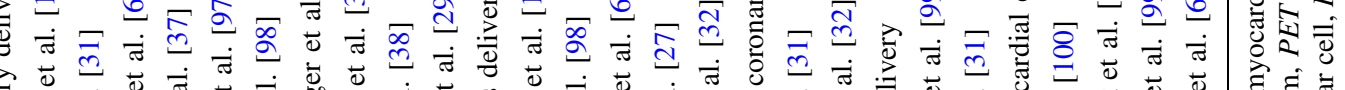

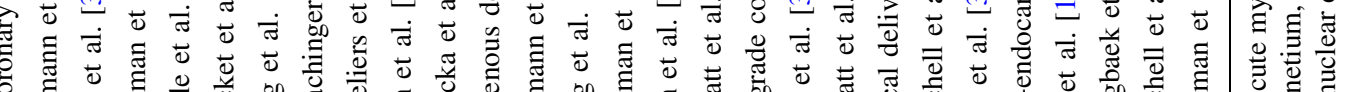

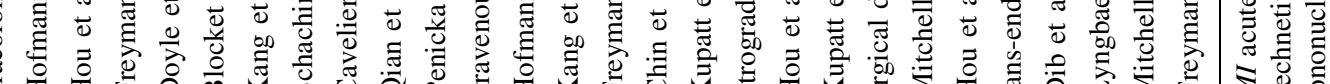

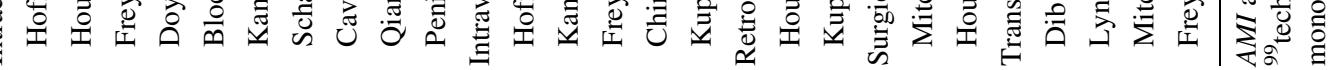


(Boston Scientific SciMed, Natick, MA) [10, 72], Bioheart Myocath (Santa Rosa, CA), the Helix needle catheter (being developed) (BioCardia, CA) and Biosense Webster Myostar (Diamond Bar, CA) [5]. All above stated devices are developed for cell and gene based therapies.

In general, IM injection of cells requires extensive fluoroscopic guidance to navigate within the ventricle, which is an important drawback for both patient and operator. To overcome this issue, the Myostar catheter is incorporated into a three dimensional electromechanical mapping system (NOGA). The target area can be determined by identifying viable, hibernating and infarcted myocardium, without the need of fluoroscopic guidance. Therapeutic cells can be injected in the region of interest, that is defined as a 'mismatch' area, i.e. presence of electrical activity in absence of mechanical movement. The use of the NOGA system was generally proven to be safe and feasible in animal studies and clinical trials for cellular [5, 73] and gene [74, 75] therapy.

Perin et al. evaluated the safety and effect of TE delivered autologous BM-MNC in patients with severe heart failure. They observed an improved regional and global myocardial function compared to controls, without safety issues [5]. These encouraging results initiated a number of new trials [76-79].

Other possible advantages of this technique include: cell delivery in occluded areas and implementation of high cell concentration in the myocardial region of interest. Potential drawbacks of IM delivery are the risk of myocardial perforation due to injection [80]. Furthermore, handling of the NOGA system requires technical training, is time consuming and expensive due to the use of a separate mapping and injection catheter. Another major drawback of TE injection is that direct cell injection may alter the gap junction orientation leading to ventricular arrhythmias [81]. Also, the ischemic environment and needle puncture may lead to a release of inflammatory stimuli which could be a trigger for arrhythmias [82]. Cellular retention ranges from 3 to $54 \%$ after TE injection. This wide variety is due to differences in animal model, TE catheter, cell type, imaging method and study design (see Table 3 ).

Over the past years, TE has rapidly evolved from an experimental technique towards a promising IM delivery technique. In the coming years research should focus on determining the most efficient TE catheter and long-term effects of this strategy.
Retrograde coronary transvenous injection

During a routine transvenous catheterization procedure a roadmap coronary venogram will be performed to gain access to all areas of the heart. Of note: no left-sided catheterization procedure is necessary for this technique. A composite catheter (TransAccess, Menlo Park, California) with a nitinol needle will be inserted into the venous wall under intravascular ultrasound, followed by microinfusion of stem cells by an IntraLume (Trans Vascular Inc.) catheter that will penetrate the myocardium under fluoroscopic guidance [83]. Thompson et al. [83] were the first to demonstrate the safety and feasibility of RCV delivery in a non-infarcted swine model. In addition, retrograde infusion of bone marrow cells induced angiogenesis and improved cardiac function in ischemic pigs compared to controls [84]. It was shown that RCV is a safe and feasible method for myoblast transplantation in patients 3 months after MI [85]. The authors also suggested that the RCV catheter rotates better which may improve target accuracy compared to TE injection. Furthermore, $\mathrm{RCV}$ is advantageous in cost, time performance thereby preventing cell loss and may enter thinned myocardium $(<5 \mathrm{~mm})$ due its co-axial injection technique [83, 84]. However, possible irreversible damage to the venous wall may occur during the injection procedure [86] and it is technical difficult to implement cells in the coronary venous system. With this technique only access to the anterior wall can be achieved, and only along the veins anatomy. Incorrect position of the needle may cause perforation of the venous wall leading to a pericardial hemorrhage. A small number of studies [83-86] have been conducted, but it is still early to draw a conclusion regarding the efficacy of RCV.

Other delivery methods

Cell transplantation into the coronary venous system and the pericardial space has been tested in preclinical models and may have promising clinical applications in the future. Local intrapericardial delivery can be achieved by transatrial or subxyphoid access [87, 88]. Both techniques were well tolerated without apparent complications. However, to our knowledge no studies have investigated cell injections to the injured heart. Moreover, clinical 
experience with this technique is limited. Only one study has been conducted so far [89].

Coronary sinus venous infusion is performed by advancing a single or double balloon catheter via the coronary sinus into the area of interest [31, 90]. Before cell infusion, a detailed anatomical map will be obtained by a coronary sinus venogram. During the procedure infusion pressure should be monitored closely to prevent disruption of the venocappillary system [91]. Studies have shown that it is feasible to access most myocardial segments through the cardiac venous system [92]. Therefore, this technique may be an alternative for patients with a coronary arterial occlusion. Compared to IC delivery brief periods of venous balloon occlusion are unlikely to cause clinical complaints or myocardial ischemia due to the existence of venous anastomoses [92]. The limitations of this approach are similar to RCV injections.

It was demonstrated that coronary venous infusion does not produce hemodynamical changes in a porcine model of myocardial injury. The authors concluded that this strategy was effective because autologous unfractioned bone marrow cells were observed in the myocardium and enhanced angiogenesis [93]. Later, the same research group conducted a prospective study in 14 patients with chronic stable angina. Autologous cell infusion was safe and tolerable. Significant improvement in myocardial perfusion and EF were observed during follow-up. Coronary angiography showed more collateral vessels in 9/14 patients [94]. However, these results do not prove efficacy assessed by a randomized trial.

\section{Comparison of delivery techniques}

Hou et al. assessed cell distribution of human mononuclear cells after surgical, IC and coronary venous delivery in an ischemic swine model. Only $11,2.6$ and $3.2 \%$ were retained in the heart after surgical, IC and venous delivery, respectively [31]. Although surgical delivery appeared to be the most efficient technique, there was a huge variation in efficiency. The group of Freyman compared allogenic MSC engraftment after IV, IC and IM (Stiletto) delivery in a porcine MI model [69]. They found that IC delivery was associated with significant higher engraftment rates after 14 days compared to IM and IV. However, decreased coronary bloodflow and greater myocardial injury were observed after IC delivery. This could be due to high cell numbers injected. Perin et al. [6] demonstrated that IM injection (using NOGA technology) of autologous MSC significantly improved left ventricle EF and reduced myocardial ischemia in a canine model. Conversely, no change in the IC group was observed. Another study compared IM and RCV delivery of microspheres and found no significant difference in myocardial retention between these techniques. The authors also suggested that IM injection is superior to $\mathrm{RCV}$ in the infarct region, but that RCV is preferred for treatment of the peri-infarct region were to be treated based on differences in target areas of the devices [95]. Recently, it was demonstrated that RCV injection of BM-MNC is better than IC delivery in view of cell retention and tissue penetration in an acute MI model. However, the study is limited by a very small sample size ( $n=2$ per group) [96].

In summary, several large animal studies showed conflicting results in the efficacy of different transplantation strategies. Notably, the optimal transplantation technique also depends on type of model (acute MI vs. chronic heart failure). To provide a definite answer to the most optimal delivery strategy, we believe that a randomized trial in a clinically relevant animal model (porcine) is necessary, using state-ofthe-art cell tracking techniques, including determination of biodistribution after the various delivery strategies.

\section{Conclusion}

Cell based cardiac repair showed beneficial effect on myocardial function in animal experiments. A number of clinical trials have already been conducted, although important unresolved issues concerning cell therapy are present. Interestingly, the most optimal delivery strategy still needs to be determined. Noninvasive imaging plays an essential role in determining biodistribution, survival and functional effects to the heart, that is of importance for several aspects of cell therapy (e.g. delivery strategy, cell type). Imaging parameters like contractility, perfusion, and viability of myocardium do not grant direct visualization of transplanted cells. New advancements in MRI and nuclear imaging have shown to provide reliable and highly sensitive visualization of 
transplanted cells, although mainly performed in animal models. The introduction of molecular cell tracking will contribute immensely to future studies of cellular mechanisms attributable to functional improvement. Until now, a small number of studies compared biodistribution between different delivery techniques in acute MI models. Unfortunately, results are still inconclusive due to differences in cell type, animal model, labeling method and delivery techniques.

In view of clinical trials it is important to determine the most optimal delivery strategy in a pre-clinical MI model using state-of-the-art cell tracking for both biodistribution and long-term survival. Adequate cell tracking is essential to guide molecular approaches to enhance homing, engraftment and survival of transplanted stem cells. Therefore, additional and more focused pre-clinical studies are mandatory before designing new clinical trials.

Acknowledgments This work was supported by the Netherlands Heart Foundation '[2003B07304 and 2010T025]', BSIK program "Dutch Program for Tissue Engineering", '[grant 6746]', and a Bekalis price (PD). This research also forms part of the Project P1.04 SMARTCARE of the research program of the BioMedical Materials institute, co-funded by the Dutch Ministry of Economic Affairs.

Open Access This article is distributed under the terms of the Creative Commons Attribution Noncommercial License which permits any noncommercial use, distribution, and reproduction in any medium, provided the original author(s) and source are credited.

\section{References}

1. Rosamond W, Flegal K, Furie K, Go A, Greenlund K, Haase N, Hailpern SM, Ho M, Howard V, Kissela B, Kittner S, Lloyd-Jones D, McDermott M, Meigs J, Moy C, Nichol G, O’Donnell C, Roger V, Sorlie P, Steinberger J, Thom T, Wilson M, Hong Y, for the American Heart Association Statistics Committee, Stroke Statistics Subcommittee (2008) Heart disease and stroke statistics2008 update: a report from the American Heart Association Statistics Committee and Stroke Statistics Subcommittee. Circulation 117:e25-146

2. World Health Organization (2007) The atlas of heart disease and stroke. pp 48-49

3. Halkos M, Zhao ZQ, Kerendi F, Wang NP, Jiang R, Schmarkey L, Martin B, Quyyumi A, Few W, Kin H, Guyton R, Vinten-Johansen J (2008) Intravenous infusion of mesenchymal stem cells enhances regional perfusion and improves ventricular function in a porcine model of myocardial infarction. Basic Res Cardiol 103:525-536
4. Hare JM, Traverse JH, Henry TD, Dib N, Strumpf RK, Schulman SP, Gerstenblith G, DeMaria AN, Denktas AE, Gammon RS, Hermiller JB Jr, Reisman MA, Schaer GL, Sherman W (2009) A randomized, double-blind, placebocontrolled, dose-escalation study of intravenous adult human mesenchymal stem cells (prochymal) after acute myocardial infarction. J Am Coll Cardiol 54:2277-2286

5. Perin EC, Dohmann HFR, Borojevic R, Silva SA, Sousa ALS, Mesquita CT, Rossi MID, Carvalho AC, Dutra HS, Dohmann HJF, Silva GV, Belem L, Vivacqua R, Rangel FOD, Esporcatte R, Geng YJ, Vaughn WK, Assad JAR, Mesquita ET, Willerson JT (2003) Transendocardial, autologous bone marrow cell transplantation for severe, chronic ischemic heart failure. Circulation 107:22942302

6. Perin EC, Silva GV, Assad JAR, Vela D, Buja LM, Sousa ALS, Litovsky S, Lin J, Vaughn WK, Coulter S, Fernandes MR, Willerson JT (2008) Comparison of intracoronary and transendocardial delivery of allogeneic mesenchymal cells in a canine model of acute myocardial infarction. J Mol Cell Cardiol 44:486-495

7. Tomita S, Mickle DAG, Weisel RD, Jia ZQ, Tumiati LC, Allidina Y, Liu P, Li RK (2002) Improved heart function with myogenesis and angiogenesis after autologous porcine bone marrow stromal cell transplantation. $\mathbf{J}$ Thorac Cardiovasc Surg 123:1132-1140

8. Orlic D, Kajstura J, Chimenti S, Jakoniuk I, Anderson SM, Li B, Pickel J, McKay R, Nadal-Ginard B, Bodine DM, Leri A, Anversa P (2001) Bone marrow cells regenerate infarcted myocardium. Nature 410:701-705

9. Wang JS, Shum-Tim D, Galipeau J, Chedrawy E, Eliopoulos N, Chiu RC (2000) Marrow stromal cells for cellular cardiomyoplasty: feasibility and potential clinical advantages. J Thorac Cardiovasc Surg 120:999-1006

10. Hill JM, Dick AJ, Raman VK, Thompson RB, Yu ZX, Hinds KA, Pessanha BSS, Guttman MA, Varney TR, Martin BJ, Dunbar CE, McVeigh ER, Lederman RJ (2003) Serial cardiac magnetic resonance imaging of injected mesenchymal stem cells. Circulation 108: 1009-1014

11. Hofmann M, Wollert KC, Meyer GP, Menke A, Arseniev L, Hertenstein B, Ganser A, Knapp WH, Drexler H (2005) Monitoring of bone marrow cell homing into the infarcted human myocardium. Circulation 111: 2198-2202

12. Kraitchman DL, Tatsumi M, Gilson WD, Ishimori T, Kedziorek D, Walczak P, Segars WP, Chen H, Fritzges D, Izbudak I, Young RG, Marcelino M, Pittenger MF, Solaiyappan M, Boston RC, Tsui BMW, Wahl RL, Bulte JWM (2005) Dynamic imaging of allogeneic mesenchymal stem cells trafficking to myocardial infarction. Circulation 112:1451-1461

13. Nolte IS, Gungor S, Erber R, Plaxina E, Scharf J, Misselwitz B, Gerigk L, Przybilla H, Groden C, Brockmann MA (2008) In vitro labeling of glioma cells with gadofluorine $\mathrm{M}$ enhances $T_{1}$ visibility without affecting glioma cell growth or motility. Magn Reson Med 59:1014-1020

14. Lewin M, Carlesso N, Tung CH, Tang XW, Cory D, Scadden DT, Weissleder R (2000) Tat peptide-derivatized magnetic nanoparticles allow in vivo tracking and recovery of progenitor cells. Nat Biotechnol 18:410-414 
15. Bulte JW, Douglas T, Witwer B, Strable E, Lewis BK, Zywicke H, Miller B, van Gelderen P, Moskowitz BM, Duncan ID, Frank JA (2001) Magnetodendrimers allow endosomal magnetic labeling and in vivo tracking of stem cells. Nat Biotechnol 19:1141-1147

16. Frank JA, Miller BR, Arbab AS, Zywicke HA, Jordan EK, Lewis BK, Bryant LH Jr, Bulte JWM (2003) Clinically applicable labeling of mammalian and stem cells by combining superparamagnetic iron oxides and transfection agents. Radiology 228:480-487

17. Kostura L, Kraitchman DL, Mackay AM, Pittenger MF, Bulte JW (2004) Feridex labeling of mesenchymal stem cells inhibits chondrogenesis but not adipogenesis or osteogenesis. NMR Biomed 17:513-517

18. Himes N, Min JY, Lee R, Brown C, Shea J, Huang X, Xiao YF, Morgan JP, Burstein D, Oettgen P (2004) In vivo MRI of embryonic stem cells in a mouse model of myocardial infarction. Magn Reson Med 52:1214-1219

19. Cahill KS, Germain S, Byrne BJ, Walter GA (2004) Noninvasive analysis of myoblast transplants in rodent cardiac muscle. Int J Cardiovasc Imaging 20:593-598

20. Stuckey DJ, Carr CA, Martin-Rendon E, Tyler DJ, Willmott C, Cassidy PJ, Hale SJM, Schneider JE, Tatton L, Harding SE, Radda GK, Watt S, Clarke K (2006) Iron particles for noninvasive monitoring of bone marrow stromal cell engraftment into, and isolation of viable engrafted donor cells from, the heart. Stem Cells 24:1968-1975

21. Amsalem Y, Mardor Y, Feinberg MS, Landa N, Miller L, Daniels D, Ocherashvilli A, Holbova R, Yosef O, Barbash IM, Leor J (2007) Iron-oxide labeling and outcome of transplanted mesenchymal stem cells in the infarcted myocardium. Circulation 116:I-38

22. Aicher A, Brenner W, Zuhayra M, Badorff C, Massoudi S, Assmus B, Eckey T, Henze E, Zeiher AM, Dimmeler S (2003) Assessment of the tissue distribution of transplanted human endothelial progenitor cells by radioactive labeling. Circulation 107:2134-2139

23. Bindslev L, Haack-Sorensen M, Bisgaard K, Kragh L, Mortensen S, Hesse B, Kjær A, Kastrup J (2006) Labelling of human mesenchymal stem cells with indium-111 for SPECT imaging: effect on cell proliferation and differentiation. Eur J Nucl Med Mol Imaging 33:1171-1177

24. Jin Y, Kong H, Stodilka RZ, Wells RG, Zabel P, Merrifield PA, Sykes J, Prato FS (2005) Determining the minimum number of detectable cardiac-transplanted 111In-tropolone-labelled bone-marrow-derived mesenchymal stem cells by SPECT. Phys Med Biol 19:44454455

25. Brenner W, Aicher A, Eckey T, Massoudi S, Zuhayra M, Koehl U, Heeschen C, Kampen WU, Zeiher AM, Dimmeler S, Henze E (2004) 111In-labeled CD34 + hematopoietic progenitor cells in a rat myocardial infarction model. J Nucl Med 45:512-518

26. Nowak B, Weber C, Schober A, Zeiffer U, Liehn E, von Hundelshausen P, Reinartz P, Schaefer W, Buell U (2007) Indium-111 oxine labelling affects the cellular integrity of haematopoietic progenitor cells. Eur J Nucl Med Mol Imaging 34:715-721

27. Chin BB, Nakamoto Y, Bulte JW, Pittenger MF, Whal R, Kraitchman DL (2003) 111In oxine labelled mesenchymal stem cell SPECT after intravenous administration in myocardial infarction. Nucl Med Commun 24:1149-1154

28. Patterson RB, Mayfield G, Silberstein EB, Kempczinski RF (1989) The potential unreliability of indium 111 oxine labeling in studies of endothelial cell kinetics. J Vasc Surg 10:650-655

29. Penicka M, Lang O, Widimsky P, Kobylka P, Kozak T, Vanek T, Dvorak J, Tintera J, Bartunek J (2007) One-day kinetics of myocardial engraftment after intracoronary injection of bone marrow mononuclear cells in patients with acute and chronic myocardial infarction. Heart 93:837-841

30. Barbash IM, Chouraqui P, Baron J, Feinberg MS, Etzion S, Tessone A, Miller L, Guetta E, Zipori D, Kedes LH, Kloner RA, Leor J (2003) Systemic delivery of bone marrow-derived mesenchymal stem cells to the infarcted myocardium: feasibility, cell migration, and body distribution. Circulation 108:863-868

31. Hou D, Youssef EA-S, Brinton TJ, Zhang P, Rogers P, Price ET, Yeung AC, Johnstone BH, Yock PG, March KL (2005) Radiolabeled cell distribution after intramyocardial, intracoronary, and interstitial retrograde coronary venous delivery: implications for current clinical trials. Circulation 112:I-150

32. Kupatt C, Hinkel R, Lamparter M, von Bruhl ML, Pohl T, Horstkotte J, Beck H, Muller S, Delker S, Gildehaus FJ, Buning H, Hatzopoulos AK, Boekstegers P (2005) Retroinfusion of embryonic endothelial progenitor cells attenuates ischemia-reperfusion injury in pigs: role of phosphatidylinositol 3-kinase/AKT kinase. Circulation 112:I-117

33. Lyngbaek S, Ripa R, Haack-Sorensen M, Cortsen A, Kragh L, Andersen C, Jorgensen E, Kjaer A, Kastrup J, Hesse B (2010) Serial in vivo imaging of the porcine heart after percutaneous, intramyocardially injected 111In-labeled human mesenchymal stromal cells. Int J Cardiovasc Imaging 26:273-284

34. Zhou R, Thomas DH, Qiao H, Bal HS, Choi SR, Alavi A, Ferrari VA, Kung HF, Acton PD (2005) In vivo detection of stem cells grafted in infarcted rat myocardium. J Nucl Med 46:816-822

35. Caveliers A, De Keulenaer G, Everaert H, Everaert H, Van Camp G, Verheye S, Roland J, Schoors D, Franken PR, Schots R (2007) In vivo visualization of 111In labeled CD133 + peripheral blood stem cells after intracoronary administration in patients with chronic ischemic heart disease. Q J Nucl Med Mol Imaging 51:61-66

36. Schachinger V, Aicher A, Dobert N, Rover R, Diener J, Fichtlscherer S, Assmus B, Seeger FH, Menzel C, Brenner W, Dimmeler S, Zeiher AM (2008) Pilot trial on determinants of progenitor cell recruitment to the infarcted human myocardium. Circulation 118:14251432

37. Doyle B, Kemp BJ, Chareonthaitawee P, Reed C, Schmeckpeper J, Sorajja P, Russell S, Araoz P, Riederer SJ, Caplice NM (2007) Dynamic tracking during intracoronary injection of $18 \mathrm{~F}-\mathrm{FDG}$-labeled progenitor cell therapy for acute myocardial infarction. J Nucl Med 48:1708-1714 
38. Qian H, Yang Y, Huang J, Gao R, Dou K, Yang G, Li J, Shen R, He Z, Lu M, Zhao S (2010) Intracoronary delivery of autologous bone marrow mononuclear cells radiolabeled by $18 \mathrm{~F}$-fluoro-deoxy-glucose: tissue distribution and impact on post-infarct swine hearts. J Cell Biochem 102:64-74

39. Louie AY, Hüber MM, Ahrens ET, Rothbächer U, Moats R, Jacobs RE, Fraser SE, Meade TJ (2000) In vivo visualization of gene expression using magnetic resonance imaging. Nat Biotechnol 18:321-325

40. Tjuvajev JG, Finn R, Watanabe K, Joshi R, Oku T, Kennedy J, Beattie B, Koutcher J, Larson S, Blasberg RG (1996) Noninvasive imaging of herpes virus thymidine kinase gene transfer and expression: a potential method for monitoring clinical gene therapy. Cancer Res 56:4087-4095

41. Weissleder R, Moore A, Mahmood U, Bhorade R, Benveniste $H$, Basilion JP (2000) In vivo magnetic resonance imaging of transgene expression. Nat Med 6:351-355

42. Moore A, Josephson L, Bhorade RM, Basilion JP, Weissleder R (2001) Human transferrin receptor gene as a marker gene for MR imaging. Radiology 221:244-250

43. Wu JC, Chen IY, Sundaresan G, Min JJ, De A, Qiao JH, Fishbein MC, Gambhir SS (2003) Molecular imaging of cardiac cell transplantation in living animals using optical bioluminescence and positron emission tomography. Circulation 108:1302-1305

44. Willmann JK, Paulmurugan R, Rodriguez-Porcel M, Stein W, Brinton TJ, Connolly AJ, Nielsen CH, Lutz AM, Lyons J, Ikeno F, Suzuki Y, Rosenberg J, Chen IY, Wu JC, Yeung AC, Yock P, Robbins RC, Gambhir SS (2009) Imaging gene expression in human mesenchymal stem cells: from small to large animals. Radiology 252:117127

45. Gyongyosi M, Blanco J, Marian T, Tron L, Petnehazy O, Petrasi Z, Hemetsberger R, Rodriguez J, Font G, Pavo IJ, Kertesz I, Balkay L, Pavo N, Posa A, Emri M, Galuska L, Kraitchman DL, Wojta J, Huber K, Glogar D (2008) Serial noninvasive in vivo positron emission tomographic tracking of percutaneously intramyocardially injected autologous porcine mesenchymal stem cells modified for transgene reporter gene expression. Circ Cardiovasc Imaging 1:94-103

46. Miyagawa M, Beyer M, Wagner B, Anton M, Spitzweg C, Gansbacher B, Schwaiger M, Bengel FM (2005) Cardiac reporter gene imaging using the human sodium/ iodide symporter gene. Cardiovasc Res 65:195-202

47. Shen D, Liu D, Cao Z, Acton P, Zhou R (2007) Coregistration of magnetic resonance and single photon emission computed tomography images for noninvasive localization of stem cells grafted in the infarcted rat myocardium. Mol Imaging Biol 9:24-31

48. Chen I, Greve J, Gheysens O, Willmann J, RodriguezPorcel M, Chu P, Sheikh A, Faranesh A, Paulmurugan R, Yang P, Wu J, Gambhir S (2009) Comparison of optical bioluminescence reporter gene and superparamagnetic iron oxide MR contrast agent as cell markers for noninvasive imaging of cardiac cell transplantation. Mol Imaging Biol 11:178-187

49. Hamano K, Nishida M, Hirata K, Mikamo A, Li TS, Harada M, Miura T, Matsuzaki M, Esato K (2001) Local implantation of autologous bone marrow cells for therapeutic angiogenesis in patients with ischemic heart disease clinical trial and preliminary results. Jpn Circ J 65:845-847

50. Strauer BE, Brehm M, Zeus T, Kostering M, Hernandez A, Sorg RV, Kogler G, Wernet P (2002) Repair of infarcted myocardium by autologous intracoronary mononuclear bone marrow cell transplantation in humans. Circulation 106:1913-1918

51. Chen Sl, Fang Ww, Ye F, Liu YH, Qian J, Shan Sj, Zhang Jj, Chunhua RZ, Liao Lm, Lin S, Sun Jp (2004) Effect on left ventricular function of intracoronary transplantation of autologous bone marrow mesenchymal stem cell in patients with acute myocardial infarction. Am J Cardiol 94:92-95

52. Erbs S, Linke A, Schachinger V, Assmus B, Thiele H, Diederich KW, Hoffmann C, Dimmeler S, Tonn T, Hambrecht R, Zeiher AM, Schuler G (2007) Restoration of microvascular function in the infarct-related artery by intracoronary transplantation of bone marrow progenitor cells in patients with acute myocardial infarction: the Doppler substudy of the reinfusion of enriched progenitor cells and infarct remodeling in acute myocardial infarction (REPAIR-AMI) trial. Circulation 116:366-374

53. Hirsch A, Nijveldt R, van der Vleuten PA, Biemond BJ, Doevendans PA, van Rossum AC, Tijssen JG, Zijlstra F, Piek JJ (2006) Intracoronary infusion of autologous mononuclear bone marrow cells or peripheral mononuclear blood cells after primary percutaneous coronary intervention: rationale and design of the HEBE trial-a prospective, multicenter, randomized trial. Am Heart J 152:434-441

54. Janssens S, Dubois C, Bogaert J, Theunissen K, Deroose C, Desmet W, Kalantzi M, Herbots L, Sinnaeve P, Dens J, Maertens J, Rademakers F, Dymarkowski S, Gheysens O, Van Cleemput J, Bormans G, Nuyts J, Belmans A, Mortelmans L, Boogaerts M, Van de Werf F (2006) Autologous bone marrow-derived stem-cell transfer in patients with ST-segment elevation myocardial infarction: double-blind, randomised controlled trial. Lancet 367:113-121

55. Kang HJ, Kim HS, Zhang SY, Park KW, Cho HJ, Koo BK, Kim YJ, Lee DS, Sohn DW, Han KS, Oh BH, Lee MM, Park YB (2004) Effects of intracoronary infusion of peripheral blood stem-cells mobilised with granulocytecolony stimulating factor on left ventricular systolic function and restenosis after coronary stenting in myocardial infarction: the MAGIC cell randomised clinical trial. Lancet 363:751-756

56. Lunde K, Solheim S, Aakhus S, Arnesen H, Abdelnoor M, Egeland T, Endresen K, Ilebekk A, Mangschau A, Fjeld JG, Smith HJ, Taraldsrud E, Grogaard HK, Bjornerheim R, Brekke M, Muller C, Hopp E, Ragnarsson A, Brinchmann JE, Forfang K (2006) Intracoronary injection of mononuclear bone marrow cells in acute myocardial infarction. N Engl J Med 355:1199-1209

57. Schachinger V, Assmus B, Britten MB, Honold J, Lehmann R, Teupe C, Abolmaali ND, Vogl TJ, Hofmann WK, Martin H, Dimmeler S, Zeiher AM (2004) Transplantation of progenitor cells and regeneration enhancement in acute myocardial infarction: final one-year results 
of the TOPCARE-AMI trial. J Am Coll Cardiol 44:16901699

58. Strauer BE, Brehm M, Zeus T, Bartsch T, Schannwell C, Antke C, Sorg RV, Kogler G, Wernet P, Mnller HW, Kostering M (2005) Regeneration of human infarcted heart muscle by intracoronary autologous bone marrow cell transplantation in chronic coronary artery disease: the IACT study. J Am Coll Cardiol 46:1651-1658

59. Wollert KC, Meyer GP, Lotz J, Ringes Lichtenberg S, Lippolt P, Breidenbach C, Fichtner S, Korte T, Hornig B, Messinger D, Arseniev L, Hertenstein B, Ganser A, Drexler H (2004) Intracoronary autologous bone-marrow cell transfer after myocardial infarction: the BOOST randomised controlled clinical trial. Lancet 364:141-148

60. Ge J, Li Y, Qian J, Shi J, Wang Q, Niu Y, Fan B, Liu X, Zhang S, Sun A, Zou Y (2006) Efficacy of emergent transcatheter transplantation of stem cells for treatment of acute myocardial infarction (TCT-STAMI). Heart 92:1764-1767

61. Schaefer A, Zwadlo C, Fuchs M, Meyer GP, Lippolt P, Wollert KC, Drexler H (2010) Long-term effects of intracoronary bone marrow cell transfer on diastolic function in patients after acute myocardial infarction: 5-year results from the randomized-controlled BOOST trial-an echocardiographic study. Eur J Echocardiogr 11:165-171

62. Yousef M, Schannwell CM, Kostering M, Zeus T, Brehm M, Strauer BE (2009) The BALANCE study: clinical benefit and long-term outcome after intracoronary autologous bone marrow cell transplantation in patients with acute myocardial infarction. J Am Coll Cardiol 53:22622269

63. Segers VFM, Lee RT (2008) Stem-cell therapy for cardiac disease. Nature 451:937-942

64. Hirsch A, Nijveldt R, van der Vleuten PA, Tio RA, van der Giessen WJ, Marques KMJ, Doevendans PA, Waltenberger J, ten Berg JM, Aengevaeren WRM, Biemond BJ, Tijssen JG, van Rossum AC, Piek JJ, Zijlstra F (2008) Intracoronary infusion of autologous mononuclear bone marrow cells in patients with acute myocardial infarction treated with primary PCI: pilot study of the multicenter HEBE trial. Catheter Cardiovasc Interv 71:273-281

65. Meluzin J, Mayer J, Groch L, Janousek S, Hornacek I, Hlinomaz O, Kala P, Panovsky R, Prasek J, Kaminek M, Stanicek J, Klabusay M, Koristek Z, Navratil M, Dusek L, Vinklarkova J (2006) Autologous transplantation of mononuclear bone marrow cells in patients with acute myocardial infarction: the effect of the dose of transplanted cells on myocardial function. Am Heart J 152:975

66. Vulliet PR, Greeley M, Halloran SM, MacDonald KA, Kittleson MD (2004) Intra-coronary arterial injection of mesenchymal stromal cells and microinfarction in dogs. Lancet 363:783-784

67. Bartunek J, Vanderheyden M, Vandekerckhove B, Mansour S, De Bruyne B, De Bondt P, Van Haute I, Lootens $\mathrm{N}$, Heyndrickx G, Wijns W (2005) Intracoronary injection of CD133-positive enriched bone marrow progenitor cells promotes cardiac recovery after recent myocardial infarction: feasibility and safety. Circulation 112:I-178

68. Tossios P, Krausgrill B, Schmidt M, Fischer T, Halbach M, Fries JWU, Fahnenstich S, Frommolt P, Heppelmann I, Schmidt A, Schomacker K, Fischer JH, Bloch W,
Mehlhorn U, Schwinger RHG, Muller-Ehmsen J (2008) Role of balloon occlusion for mononuclear bone marrow cell deposition after intracoronary injection in pigs with reperfused myocardial infarction. Eur Heart J 29: 1911-1921

69. Freyman T, Polin G, Osman H, Crary J, Lu M, Cheng L, Palasis M, Wilensky RL (2006) A quantitative, randomized study evaluating three methods of mesenchymal stem cell delivery following myocardial infarction. Eur Heart J 27:1114-1122

70. Price MJ, Chou CC, Frantzen M, Miyamoto T, Kar S, Lee S, Shah PK, Martin BJ, Lill M, Forrester JS, Chen PS, Makkar RR (2006) Intravenous mesenchymal stem cell therapy early after reperfused acute myocardial infarction improves left ventricular function and alters electrophysiologic properties. Int J Cardiol 111:231-239

71. Boekstegers P, Giehrl W, Degenfeld Gv, Steinbeck G (1998) Selective suction and pressure-regulated retroinfusion: an effective and safe approach to retrograde protection against myocardial ischemia in patients undergoing normal and high risk percutaneous transluminal coronary angioplasty. J Am Coll Cardiol 31:15251533

72. Schuleri KH, Amado LC, Boyle AJ, Centola M, Saliaris AP, Gutman MR, Hatzistergos KE, Oskouei BN, Zimmet JM, Young RG, Heldman AW, Lardo AC, Hare JM (2008) Early improvement in cardiac tissue perfusion due to mesenchymal stem cells. Am J Physiol Heart Circ Physiol 294:H2002-H2011

73. Tse HF, Kwong YL, Chan JK, Lo G, Ho CL, Lau CP (2003) Angiogenesis in ischaemic myocardium by intramyocardial autologous bone marrow mononuclear cell implantation. Lancet 361:47-49

74. Kornowski R, Leon MB, Fuchs S, Vodovotz Y, Flynn MA, Gordon DA, Pierre A, Kovesdi I, Keiser JA, Epstein SE (2000) Electromagnetic guidance for catheter-based transendocardial injection: a platform for intramyocardial angiogenesis therapy: results in normal and ischemic porcine models. J Am Coll Cardiol 35:1031-1039

75. Losordo DW, Vale PR, Hendel RC, Milliken CE, Fortuin FD, Cummings N, Schatz RA, Asahara T, Isner JM, Kuntz RE (2002) Phase 1/2 placebo-controlled, doubleblind, dose-escalating trial of myocardial vascular endothelial growth factor 2 gene transfer by catheter delivery in patients with chronic myocardial ischemia. Circulation 105:2012-2018

76. Briguori C, Reimers B, Sarais C, Napodano M, Pascotto P, Azzarello G, Bregni M, Porcellini A, Vinante O, Zanco P, Peschle C, Condorelli G, Colombo A (2006) Direct intramyocardial percutaneous delivery of autologous bone marrow in patients with refractory myocardial angina. Am Heart J 151:674-680

77. Krause K, Jaquet K, Schneider C, Haupt S, Lioznov MV, Otte KM, Kuck KH (2009) Percutaneous intramyocardial stem cell injection in patients with acute myocardial infarction: first-in-man study. Heart 95:1145-1152

78. Nyolczas N, Gyongyosi M, Beran G, Dettke M, Graf S, Sochor H, Christ G, Edes I, Balogh L, Krause KT, Jaquet K, Kuck KH, Benedek I, Hintea T, Rb Kiss, Prada I, Kotevski V, Pejkov H, Dudek D, Heba G, Sylven C, Charwat S, Jacob R, Maurer G, Lang I, Glogar D (2007) 
Design and rationale for the myocardial stem cell administration after acute myocardial infarction (MYSTAR) study: a multicenter, prospective, randomized, single-blind trial comparing early and late intracoronary or combined (percutaneous intramyocardial and intracoronary) administration of nonselected autologous bone marrow cells to patients after acute myocardial infarction. Am Heart J 153:212

79. van Ramshorst J, Bax JJ, Beeres SLMA, bbets-Schneider P, Roes SD, Stokkel MPM, de Roos A, Fibbe WE, Zwaginga JJ, Boersma E, Schalij MJ, Atsma DE (2009) Intramyocardial bone marrow cell injection for chronic myocardial ischemia: a randomized controlled trial. JAMA 301:1997-2004

80. Gyongyosi M, Lang I, Dettke M, Beran G, Graf S, Sochor H, Nyolczas N, Charwat S, Hemetsberger R, Christ G, Edes I, Balogh L, Krause KT, Jaquet K, Kuck KH, Benedek I, Hintea T, Kiss R, Preda I, Kotevski V, Pejkov H, Zamini S, Khorsand A, Sodeck G, Kaider A, Maurer G, Glogar D (2009) Combined delivery approach of bone marrow mononuclear stem cells early and late after myocardial infarction: the MYSTAR prospective, randomized study. Nat Clin Pract Cardiovasc Med 6:70-81

81. Gutstein DE, Morley GE, Tamaddon H, Vaidya D, Schneider MD, Chen J, Chien KR, Stuhlmann H, Fishman GI (2001) Conduction slowing and sudden arrhythmic death in mice with cardiac-restricted inactivation of Connexin43. Circ Res 88:333-339

82. Klein RM, Vester EG, Brehm MU, Dees H, Picard F, Niederacher D, Beckmann MW, Strauer BE (2000) Inflammation of the myocardium as an arrhythmia trigger. Z Kardiol 89:24-35

83. Thompson CA, Nasseri BA, Makower J, Houser S, McGarry M, Lamson T, Pomerantseva I, Chang JY, Gold HK, Vacanti JP, Oesterle SN (2003) Percutaneous transvenous cellular cardiomyoplasty: a novel nonsurgical approach for myocardial cell transplantation. J Am Coll Cardiol 41:1964-1971

84. Yokoyama SI, Fukuda N, Li Y, Hagikura K, Takayama T, Kunimoto S, Honye J, Saito S, Wada M, Satomi A, Kato M, Mugishima H, Kusumi Y, Mitsumata M, Murohara T (2006) A strategy of retrograde injection of bone marrow mononuclear cells into the myocardium for the treatment of ischemic heart disease. J Mol Cell Cardiol 40:24-34

85. Siminiak T, Fiszer D, Jerzykowska O, Grygielska B, Rozwadowska N, Kalmucki P, Kurpisz M (2005) Percutaneous trans-coronary-venous transplantation of autologous skeletal myoblasts in the treatment of post-infarction myocardial contractility impairment: the POZNAN trial. Eur Heart J 26:1188-1195

86. Brasselet C, Morichetti MC, Messas E, Carrion C, Bissery A, Bruneval P, Vilquin JT, Lafont A, Hagege AA, Menasche P, Desnos M (2005) Skeletal myoblast transplantation through a catheter-based coronary sinus approach: an effective means of improving function of infarcted myocardium. Eur Heart J 26:1551-1556

87. Hou DM, March KL (2003) A novel percutaneous technique for accessing the normal pericardium: a singlecenter successful experience of 53 porcine procedures. J Invasive Cardiol 15:13-17
88. Waxman S, Pulerwitz TC, Rowe KA, Quist WC, Verrier RL (2000) Preclinical safety testing of percutaneous transatrial access to the normal pericardial space for local cardiac drug delivery and diagnostic sampling. Catheter Cardiovasc Interv 49:472-477

89. Macris MP, Igo SR (1999) Minimally invasive access of the normal pericardium: initial clinical experience with a novel device. Clin Cardiol 22:36-39

90. Hagikura K, Fukuda N, Yokoyama SI, Yuxin L, Kusumi Y, Matsumoto T, Ikeda Y, Kunimoto S, Takayama T, Jumabay M, Mitsumata M, Saito S, Hirayama A, Mugishima H (2009) Low invasive angiogenic therapy for myocardial infarction by retrograde transplantation of mononuclear cells expressing the VEGF gene. Int $\mathrm{J}$ Cardiol (in press, corrected proof)

91. Corday E, Meerbaum S, Drury JK (1986) The coronary sinus: an alternate channel for administration of arterial blood and pharmacologic agents for protection and treatment of acute cardiac ischemia. J Am Coll Cardiol 7:711-714

92. Herity NA, Lo ST, Oei F, Lee DP, Ward MR, Filardo SD, Hassan A, Suzuki T, Rezaee M, Carter AJ, Yock PG, Fitzgerald PJ (2000) Selective regional myocardial infiltration by the percutaneous coronary venous route: a novel technique for local drug delivery. Catheter Cardiovasc Interv 51:358-363

93. Vicario J, Piva J, Pierini A, Ortega HH, Canal A, Gerardo L, Pfeiffer H, Campos C, Fendrich I, Novero R, Monti A (2004) Transcoronary sinus delivery of autologous bone marrow and angiogenesis in pig models with myocardial injury. Cardiovasc Radiat Med 3:91-94

94. Vicario J, Campos C, Piva J, Faccio F, Gerardo L, Becker C, Ortega HH, Pierini A, Lofeudo C, Novero R, Licheri A, Milesi R, Perez Balino N, Monti A, Amin A, Pfeiffer H, De Giovanni E, Fendrich I (2004) Transcoronary sinus administration of autologous bone marrow in patients with chronic refractory stable angina: phase 1 . Cardiovasc Radiat Med 5:71-76

95. Baklanov DV, Moodie KM, McCarthy FE, Mandrusov E, Chiu J, Aswonge G, Cheng J, Chow M, Simons M, de Muinck ED (2006) Comparison of transendocardial and retrograde coronary venous intramyocardial catheter delivery systems in healthy and infarcted pigs. Catheter Cardiovasc Interv 68:416-423

96. George JC, Goldberg J, Joseph M, Abdulhameed N, Crist J, Das H, Pompili VJ (2009) Transvenous intramyocardial cellular delivery increases retention in comparison to intracoronary delivery in a porcine model of acute myocardial infarction. J Interv Cardiol 21:424-431

97. Blocklet D, Toungouz M, Berkenboom G, Lambermont M, Unger P, Preumont N, Stoupel E, Egrise D, Degaute JP, Goldman M, Goldman S (2006) Myocardial homing of nonmobilized peripheral-blood CD34 + cells after intracoronary injection. Stem Cells 24:333-336

98. Kang WJ, Kang HJ, Kim HS, Chung JK, Lee MC, Lee DS (2006) Tissue distribution of 18F-FDG-labeled peripheral hematopoietic stem cells after intracoronary administration in patients with myocardial infarction. J Nucl Med 47:1295-1301

99. Mitchell AJ, Sabondjian E, Sykes J, Deans L, Zhu W, Lu X, Feng Q, Prato FS, Wisenberg G (2010) Comparison of 
initial cell retention and clearance kinetics after subendocardial or subepicardial injections of endothelial progenitor cells in a canine myocardial infarction model. J Nucl Med 51:413-417

100. Dib N, Campbell A, Jacoby DB, Zawadzka A, Ratliff J, Miedzybrocki BM, Gahremanpour A, Diethrich EB, Opie
SR (2007) Safety and feasibility of percutaneous autologous skeletal myoblast transplantation in the coil-infarcted swine myocardium. J Pharmacol Toxicol Methods 54:71-77 